\title{
LINK BETWEEN LEARNING STRATEGIES AND EDUCATIONAL GUIDANCE NEEDS - A PILOT STUDY WITH NEW STUDENTS AT UNED
}

\author{
Borja Guerrero Bocanegra, Universidad Nacional de Educación a Distancia (UNED), Spain
}

\section{Abstract}

In institutions such as the National University of Distance Education (UNED), where students must take a leading role in their own learning processes in order to be academically successful, the learning strategies, understood as a series of cognitive, metacognitive, motivational, self-regulation, emotional and support aspects, take on maximum importance. In order to establish relationships between learning strategies and the educational guidance needs of new students at the UNED, a pilot study was carried out with students of the Degree in Psychology in March 2021, who responded to the CEVEAPEU tool developed by Gargallo et al. (2009). The data shows that, at the beginning of their degree studies, students have good learning strategies. In addition to all the initial information and advice provided by the institution, it is appropriate for guidance services to provide specific guidance on a sustained basis throughout the first year, cushioning the effect of changes that may occur in learning strategies, thus helping to prevent many dropouts.

\section{Introduction}

The transition from educational concepts focused on the teacher and on the control of the student's learning process to those focused on the student and on the improvement of his or her learning process is closely related to academic guidance. Personalised attention, where the main objectives are to guide and advise students, has become increasingly important in the context of university higher education, as it is considered a key factor in enhancing retention or preventing students from dropping out.

The Distance Education, particularly those in virtual environments, is growing exponentially. With it, dropout rates also increase, especially in the first year (SánchezElvira, 2014), which makes this initial stage critical. According to Carrión (2005), since the UNED was founded in 1972, dropout rates, that is to say, students who do not re-enrol, would be around $50 \%$ for those who drop out without even receiving a qualification (non- 
Guerrero Bocanegra, $B$.

Link between Learning Strategies and Educational Guidance Needs - A Pilot Study with New Students at UNED

starting dropout), and around $14 \%$ for those who have actually obtained a qualification (real dropout). This data suggests that acting early, before enrolment and during the first year, is key to avoiding some of these dropouts (Luque et al, 2013). Therefore, the population of new enrolled students in Distance Education is one of the groups most susceptible to dropout, indicating that research for the prevention of it during the first year should be an institutional intervention strategy with high priority, especially with regard to issues concerning student autonomy and self-regulation of learning (Sánchez, opus cit.) and that are the direct competence of educational guidance services.

There is agreement that investment in improving the learning strategies that students deploy in order to take advantage of the resources available to them, as well as to discover what, how, and when to learn, is more academically cost-effective than improving instructional techniques or teaching materials (Gonzales \& Diaz, 2007). Although the causes associated with dropout are complex and varied, and can be attributed either to the student, the teacher or the institution itself (García Aretio, 2019), investigating aspects such as lack of time, study techniques, motivation, capacity for autonomy and selfdiscipline, academic and social integration, etc. that are attributable to students, can provide clues to the institution on how to improve its guidance services. From this perspective, examining "the organised, conscious and intentional set of what the learner does to effectively achieve a learning objective in a given social context by integrating affective-motivational and supportive, metacognitive and cognitive elements" (Gargallo et al, 2009; p.2), in the initial stages of their university career can give us a global idea of the educational guidance needs of this group and how to optimise educational guidance services by focusing them on their real demands.

\section{Method}

\section{Participants}

The sample was selected by non-probabilistic convenience sampling, considering two criteria: first enrolment and degree, that is to say, first enrolment in the UNED in the academic year 2020-2021 and in the Degree in Psychology. Only students enrolled for the first time were encouraged to participate. However, a total of 99 students responded, of which 33 students who had already been enrolled on previous occasions were discarded. The sample consisted of 66 new students (60 women and 6 men), with an average age of 32.68 years. 
Guerrero Bocanegra, B.

Link between Learning Strategies and Educational Guidance Needs - A Pilot Study with New Students at UNED

\section{Instrument}

CEVEAPEU instrument developed by Gargallo et al. (2009) consists of 88 items, to be answered on a Likert-type scale with five grades. The 88 items are organised into two scales, six subscales and twenty-five strategies as shown in Table 1. Some examples of questions for the twenty-five strategies are:

- Intrinsic motivation: "What I find most satisfying is a thorough understanding of the content".

- Extrinsic motivation: "I study so I don't let my family and the people I care about down".

- Value of homework: "What I learn in some subjects I will be able to use in others and also in my future career".

- Internal attribution: "My academic performance depends on my effort".

- External attribution. "My academic performance depends on the teachers".

- Self-efficacy and expectations: "I am confident that I can understand even the most difficult content of the subjects in this course".

- Conception of intelligence as modifiable: "Intelligence is either there or it is not and cannot be improved".

- Physical and mental state: "Normally I feel good physically".

- Anxiety control: "When I take an exam, I get very nervous".

- Knowledge of the objectives and the evaluation criteria: "I know the assessment criteria by which I will be assessed by the teachers in the different subjects".

- Planning: "I plan my time to work on subjects throughout the course".

- Self-assessment: "I know what my strengths and weaknesses are when it comes to learning the subjects".

- Control / Self-regulation: "When I see that my initial plans do not achieve the expected success in my studies, I change them for more suitable ones".

- Context control: "I work and study in a suitable place - light, temperature, ventilation, noise, necessary materials at hand, etc.”.

- Social interaction skills and work with fellow classmates: "I try to study or do class work with other classmates".

- Knowledge of sources and search for information: "I know where you can get the materials you need to study the subjects".

- Selection of the de information: "I am able to select the necessary information to study the subjects with guarantees".

- Knowledge building: "When I study, I integrate information from different sources: lectures, readings, practical work, etc.”. 
- $\quad$ Preparation of the information: "When I study the topics of the subjects, I do a first reading in order to get an idea of the basics".

- Organisation of the information: "I make simple graphs, diagrams or tables to organise the subject matter".

- Personalisation and creativity. Critical thinking: "I critically analyse the concepts and theories presented to me by teachers".

- Storing and mnemonics: "To memorise I use mnemonic resources such as acronyms (I make a word with the first letters of several sections I have to learn), acronyms, key words, etc.”.

- Storage. Simple repetition: “To learn things, I just repeat them over and over again”.

- Transfer. Use of information. "I use what I have learnt at university in everyday life situations".

- $\quad$ Resource management to use information effectively: "I make use of keywords that I have studied and learned, to remember the content related to them".

\section{Procedure}

The invitation to participate in this pilot was launched through unofficial channels of the institution. Specifically in WhatsApp groups of first-year Psychology subjects at the UNED, just after the February 2021 exams.

\section{Data design and analysis}

The design of the survey was type quantitative transactional. With the statistical analysis carried out with the SPSS 17.0 software, descriptive quantitative data was obtained, specifically; frequencies, percentages, means and standard deviations.

\section{Results}

The subscale "Motivational strategies" concentrates "very high" response scores in three of the strategies; "Intrinsic motivation" $(X=13.84, \mathrm{SD}=1.61)$; "Value of homework" $(X=18.65, \mathrm{SD}=1.68)$ and "Internal attribution" $(X=12.57, \mathrm{SD}=2.30)$, "high" in other two; "Self-efficacy and expectations" $(X=15.96, \quad S D=2.72)$ and "Conception of intelligence as modifiable" $(X=6.03, \mathrm{SD}=0.89)$, "low" in "External attribution" $(X=5.12, S D=1.98)$ and "intermediate" in "Extrinsic motivation" $(X=4.54, S D=2.34)$. The scores, combined with the high scores obtained in the strategies that constitute the "Affective Component", "Physical and mental state" $(X=14.53, \mathrm{SD}=3.38)$ and "Anxiety control" ( $X=13.10, \mathrm{SD}=2.56)$, show that the students in the sample are more intrinsically than extrinsically motivated, that is, they study Psychology more for satisfaction than for external incentives, they focus more on the process than on the result, they attribute their performance fundamentally to individual characteristics and traits, and they do so in a good state of mind and dominate their anxiety in the face of tasks and exams. 

at UNED

The subscale "Metacognitive Strategies" obtains "high" scores for all the strategies, as can be seen in Table 1, with a "very high" score for the strategy "Control / Self-regulation" $(X=24.25, S D=3.46)$, which suggest that the learners surveyed possess planning, monitoring and evaluation skills that enable them to pay adequate attention to the development of their own learning processes.

In the subscale "Strategies of contextual control, social interaction and resource management", the strategies "Context control and Social interaction skills and work with fellow classmates" shows "high" scores as referred to in Table 1. Similarly, the strategic patterns associated with "Knowledge of sources and search for information" and "Selection of the information" obtain "high" scores (see Table 1).

Finally, "Strategies for information processing and use" scored "very high" in "Preparation of the information $(X=16.80, \mathrm{SD}=2.53)$ and "Transfer and use of information" ( $X=12.62, \mathrm{SD}=1.90)$, and "high" scores in "knowledge building" $(X=10.30, \mathrm{SD}=3.01)$; "Organisation of the information" $(X=19.00, \mathrm{SD}=4.33)$; "Personalisation and creativity. Critical thinking" $(X=18.07, \mathrm{SD}=4.02)$; "Storing and mnemonics" $(X=11.07$, $\mathrm{SD}=3.11)$; "Resource management to use information effectively" $(X=7.36, \mathrm{SD}=1.60)$.

Table 1: $\quad$ Results of the questionnaire CEVEAPEU

\begin{tabular}{lllrr}
\hline Scales & Subscales & Dimension & \multicolumn{1}{c}{ X } & SD \\
\hline Affective strategies & Motivational & Intrinsic motivation & 13.84 & 1.61 \\
of support and & strategies & Extrinsic motivation & 4.54 & 2.34 \\
control (self- & & Value of homework & 18.65 & 1.68 \\
management) & & Internal attribution & 12.57 & 2.30 \\
& & External attribution & 5.12 & 1.98 \\
& & Self-efficacy and expectations & 15.96 & 2.72 \\
& & Conception of intelligence as & 6.03 & 0.89 \\
& & modifiable & & \\
& Affective & Physical and mental state & 14.53 & 3.38 \\
& components & Anxiety control & 13.10 & 2.56 \\
& Metacognitive & Knowledge of the objectives & 7.57 & 1.78 \\
& strategies & and the evaluation criteria & 13.21 & 2.23 \\
& & Planning & 11.21 & 2.16 \\
& & Self-assessment & 24.25 & 3.46 \\
& & Control / Self-regulation & 15.28 & 3.69 \\
& Context & Context control & 19.86 & 4.89
\end{tabular}


Guerrero Bocanegra, $B$.

Link between Learning Strategies and Educational Guidance Needs - A Pilot Study with New Students at UNED

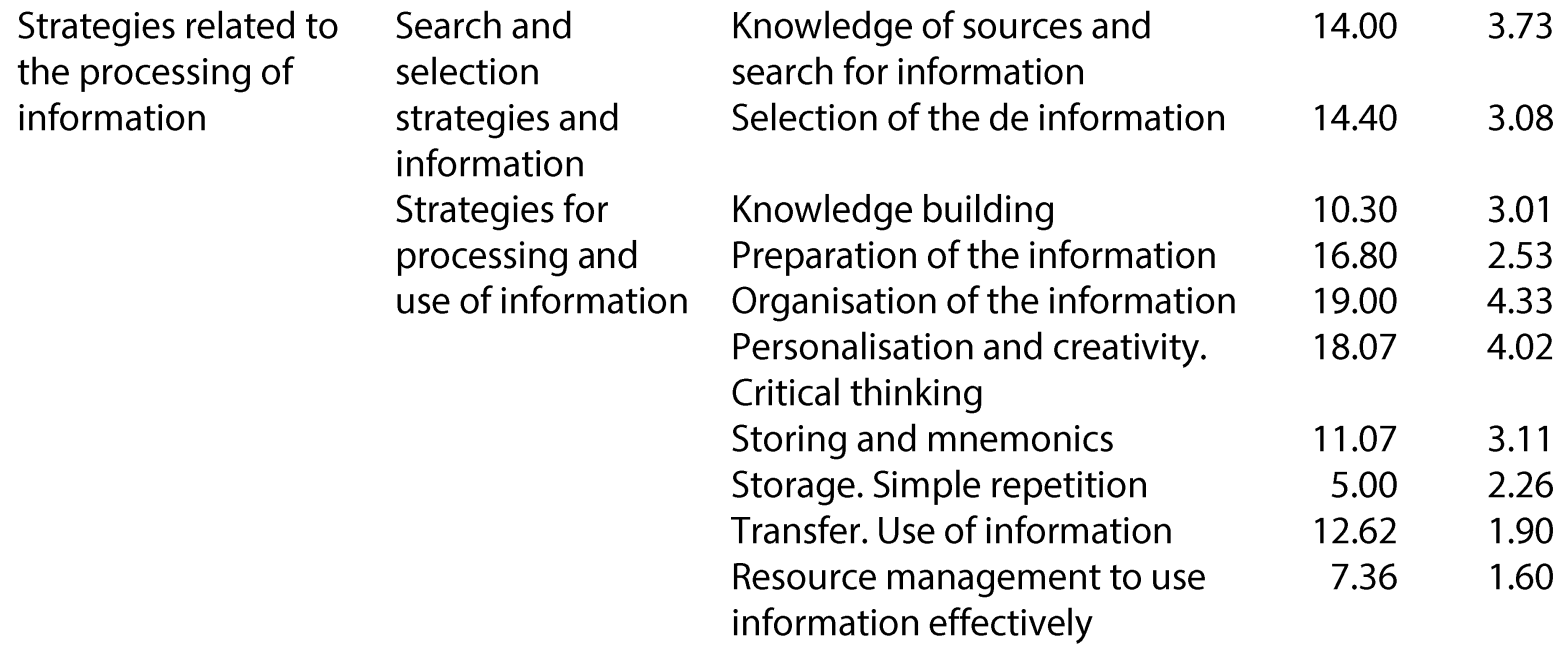

\section{Discussion and conclusions}

Taking the scores as a whole, we can see that the selected sample of students has an adequate strategic profile to start distance learning studies. The results obtained in the subscale "Motivational strategies", which is the one with the highest concentration of "very high" scores, suggest that the high initial motivation obtained by first degree students at the UNED may decrease at some point during the first year. Analysing the evolution of learning strategies over time during the first year can provide clues as to the critical moments when motivation begins to wane. UNED counselling services should focus on discovering how and when high starting motivation fluctuates at different points in the first year and on helping to sustain it by providing support and appropriate materials. On the other hand, monitoring students who make pessimistic or low mood comments as indicators associated with dropping out can help.

According to the results of the subscale "Metacognitive strategies", students do not seem to need special counselling in these aspects, in the same way that they report to know how to create suitable environmental conditions, to have a good control of time and space and a good management of material etc., (subscale "Strategies of context control, social interaction and resource management"), which are the direct competence of the guidance services. On the other hand, the "high" and "very high" scores obtained in the subscale "Strategies of information processing and use" except in the strategy "Storage. Simple repetition", tell us that the students have good strategies for encoding, processing, storing and organising information. Similar to the motivational aspects, it seems interesting to note when significant changes occur during the first year, because students "who do not reconfigure their styles despite needing to do so are likely to have greater difficulties in assimilating content, thus taking up more time and effort, and drop out" (Freiberg et al., 
2017; p.514). In addition to all the initial information and advice provided by the institution, it seems relevant for guidance services to provide specific guidance on a sustained basis throughout the first year, cushioning the effect of significant changes in learning strategies during the first year and helping to prevent dropout. Self-regulated learning is fundamental to success in distance learning modalities (Jansen et al., 2020). Thus, some of the actions that guidance services should insist on have to do with: better management and organisation of time, self-regulated study (teaching to set goals, orienting action in line with goals, planning, persistence, asking for help when necessary, trying other alternatives and reflecting) and realistic management of expectations. Provide courses on the technological skills needed to study in digital Distance Education, as well as help guides for the use of the different platforms.

The most striking limitations of this pilot experience are the sample; the size was not sufficient and the selection procedure was not impartial. As it is a convenience sample, which is not representative of the entire group of new undergraduate students at the UNED, the results cannot be generalised. Systematic replication on a larger scale is needed.

\section{References}

Álvarez, P. R., \& López, D. (2017). Estudios sobre deserción académica y medidas orientadoras de prevención en la universidad de La Laguna (España). Revista Paradigma, 38(1), 48-71. Retrieved from https://goo.gl/mC5SM3.

Cabrera, L., Bethencourt, J. T., Álvarez, P., \& González, M. (2006). El problema del abandono de los estudios universitarios. RELIEVE, 1(2). https://doi.org/10.7203/relieve.12.2.4226

Carrión, J. (2005). Una mirada crítica a la Enseñanza a Distancia (segunda parte). Revista Iberoamericana de Educación, 36(12), 1-13. https://doi.org/10.35362/rie36122740

Freiberg, A., Ledesma, R., \& Fernández, M. (2017). Estilos y estrategias de aprendizaje en estudiantes universitarios de Buenos Aires. Revista de Psicología, 35(2), 511-49. https://doi.org/10.18800/psico.201702.006

García Aretio, L. (2019). El problema del abandono en estudios a distancia. Respuestas desde el Diálogo Didáctico Mediado. RIED. Revista Iberoamericana de Educación a Distancia, 22(1), 245-270. http://dx.doi.org/10.5944/ried.22.1.22433

Gargallo, B., Suárez-Rodríguez, J., \& Pérez-Pérez, C. (2009). El cuestionario CEVEAPEU. Un instrumento para la evaluación de las estrategias de aprendizaje de los estudiantes universitarios. RELIEVE. Revista Electrónica de Investigación y Evaluación Educativa, 15(2), 1-31. Retrieved from https://www.redalyc.org/pdf/916/91612906006.pdf 
Guerrero Bocanegra, $B$.

Link between Learning Strategies and Educational Guidance Needs - A Pilot Study with New Students at UNED

Gargallo, B., Almerich, G., Suárez-Rodríguez, J., \& García-Félix, E. (2012). Estrategias de aprendizaje en estudiantes universitarios excelentes y medios. Su evolución a lo largo del primer año de carrera. Revista Electrónica de Investigación y Evaluación Educativa, 18(2). https://doi.org/10.7203/relieve.18.2.2000

Gonzales, D., \& Díaz, Y. (2007). La importancia de promover en el aula estrategias de aprendizaje para elevar el nivel académico en los estudiantes de Psicología. Revista Iberoamericana de Educación, 46(8). Retrieved from https://rieoei.org/historico/investigacion/1379Gonzalez.pdf

Jansen, R., Leeuwen, A., Janssen, J., Conijn, R., \& Kester, L. (2020). Supporting learners' self-regulated learning in Massive Open Online Courses. Computers \& Education, 146. Retrieved from https://www.sciencedirect.com/science/article/pii/S0360131519303240

Luque, E., García, F., \& de Santiago, C. (2013). El abandono y egreso en la UNED. IUEDoc2. IUED. UNED. Retrieved from http://espacio.uned.es/fez/eserv/bibliuned:501063/Luque_et_al_Abandono_Egreso_VI_Rede s_2014.pdf

Rué, J. (2014). El abandono universitario: variables, marcos de referencia y políticas de calidad. REDU. Revista de docencia universitaria, 12(2), 281-306. https://doi.org/10.4995/redu.2014.5649

Sánchez-Elvira, A. (2014). ¿Cómo iniciarse con éxito en el aprendizaje en línea?: La experiencia de la UNED en el entrenamiento de estudiantes autorregulados. En Los Recursos de Aprendizaje en Educación a Distancia: Nuevos Escenarios, Experiencias y Tendencias (pp. 144-173) Fidel Ramírez Prado y Claudio Rama. Retrieved from http://e-spacio.uned.es/fez/eserv/bibliuned:501049/Sanchez-Elvira_Iniciarseexito.pdf

\section{Author}

Trainee researcher at the International Doctoral School of the National University of Distance Education (UNED) in the Education Programme. Pre-doctoral contract under the UNED-Banco Santander 2019 Collaboration Agreement in the project "Detection of academic guidance needs of incoming students and proposal of a support programme" of the COIE. 